New host record for three scuttle flies, Megasel i a flava, $\mathrm{M}$ kanekoi and $\mathrm{M}$ got oi ( Di pt er a: Phor i dae), on the poi sonous f ungus Amani ta i bot engut ake ( Agar i cal es: Amani t aceae)

\begin{tabular}{|l|l|}
\hline 著者 & $\begin{array}{l}\text { Yamashi ta H roshi, Tanaka Chi hi ro, Nakayana } \\
\text { H r ot o, Tuno Nobuko, Osawa Naoya }\end{array}$ \\
\hline 著者別表示 & 山下 浩, 都野 展子 \\
\hline $\begin{array}{l}\text { j our nal or } \\
\text { publ i cat i on ti tl e }\end{array}$ & Ent omol ogi cal Sci ence \\
\hline vol une & 8 \\
\hline nunber & 3 \\
\hline page range & $223-225$ \\
\hline year & $2005-09-01 \quad$ doi: 10.1111/j.1479-8298.2005.00119.x \\
\hline URL & ht t p: //doi . or g/10. 24517/00011035 \\
\hline
\end{tabular}




\title{
New host record for three scuttle flies, Megaselia flava, M. kanekoi and M. gotoi (Diptera: Phoridae), on the poisonous fungus Amanita ibotengutake (Agaricales: Amanitaceae)
}

\author{
Hiroshi YAMASHITA ${ }^{1}$, Chihiro TANAKA ${ }^{2}$, Hiroto NAKAYAMA ${ }^{3}$, Nobuko TUNO ${ }^{4}$ and \\ Naoya OSAWA ${ }^{1}$ \\ ${ }^{1}$ Laboratory of Forest Ecology and ${ }^{2}$ Laboratory of Environmental Mycoscience, Graduate School of Agriculture, Kyoto University, \\ Kyoto, ${ }^{3}$ Biosystematics and Natural History Laboratory, Graduate School of Social Cultural Studies, Kyusyu University, Fukuoka \\ and ${ }^{4}$ Laboratory of Vector Ecology and Environment, Institute of Tropical Medicine, Nagasaki University, Nagasaki, Japan
}

\begin{abstract}
We identified three species of fungivorous scuttle fly - Megaselia flava, M. kanekoi and M. gotoi - from eight fruit bodies of a fungus, Amanita ibotengutake, which has not previously been recorded as the host of these flies.
\end{abstract}

Key words: food habit, fungivor, fungus-insect relationship, molecular identification.

Many large, evolutionarily successful groups of insect owe much of their proliferation to fungal food sources, and fungi frequently profit from insects: insects aid fungi in spore dispersal and habitat provision, and can even supply nutrient resources (Wheeler \& Blackwell 1984). Many of the secondary metabolites present in fungi are harmful or toxic to insects in general (e.g. Martin 1979; Hanski 1989), and may be strongly involved in insectfungus interaction. Interestingly, poisonous mushrooms, such as the family Amanitaceae, which includes species toxic to mammals, have the highest proportion of polyphagous Diptera, while many edible mushrooms have the smallest proportion of polyphagous species (e.g. Kukor \& Martin 1987; Hanski 1989). Hanski (1989) suggested that spatial and temporal unpredictability of resources for fungivorous insects is the force that primarily selects for polyphagy and exposes populations to a wide range of chemicals. However, little information is available on insect-fungus interaction, particularly at the species level (Disney 1994), mainly due to the difficulty and confusion of fungi taxonomy (e.g. Oda et al. 2002). Therefore, host information for

Correspondence: Naoya Osawa, Laboratory of Forest Ecology, Graduate School of Agriculture, Kyoto University, Kyoto, 606-8502 Japan. Email: osawa@kais.kyoto-u.ac.jp

Received 2 February 2005; accepted 22 April 2005. a fungivorous insect based on the morphologically and molecularly identified fungus at species level is much needed to promote further study of insect-fungus relationships.

Amanita ibotengutake is poisonous and is one of the causal agents of Pantherina syndrome in humans (Bresinsky \& Besl 1990; Oda et al. 2002). The fruit body of this mushroom contains the neurotoxic metabolites ibotenic acid and muscimol, which are non-fatal to mammals but are highly insecticidal (Takemoto et al. 1964; Seeger \& Stijve 1980; Oda et al. 2002). We collected eight fruit bodies of A. ibotengutake on 5 October 2002 in the Kamigamo Experimental Forest of Kyoto University $\left(35^{\circ} 04^{\prime} \mathrm{N}, 135^{\circ} 45^{\prime} \mathrm{E}\right)$, Kyoto, Japan. In Japan, A. ibotengutake has long been confused with Amanita pantherina due to similarities in their habitat and the macromorphology of the fruit body. The species can be distinguished microscopically and through molecular phylogenetics (Oda et al. 2002). Subhymenial tissues are usually clamped in A. ibotengutake, whereas they are rarely clamped in A. pantherina (Jenkins 1977; Oda et al. 2002).

Differential interference contrast microscopy observations of tissues of voucher specimens were made in $30 \mathrm{mg} / \mathrm{mL} \mathrm{KOH}$. For some voucher specimens of which subhymenial tissues were difficult to observe microscopically, we analyzed the DNA sequence of the internal 
transcribed spacer (ITS) region using polymerase chain reaction (PCR) primers ITS4 and ITS5 (White et al. 1990). DNA preparation, PCR amplification and DNA sequencing were conducted following the methods of Oda et al. (1999). The resulting sequences (accession numbers AB211054-AB211057) from the voucher specimens were compared to those of A. ibotengutake deposited in the DDBJ/EMBL/GenBank nucleotide sequence database, and were identical to or showed high homology (more than 99.6\%) with those of A. ibotengutake. In the laboratory, the fruit bodies of individual mushrooms were kept on moistened vermiculite in a clear polystyrene container $(160 \mathrm{~mm}$ high, $90 \mathrm{~mm}$ in diameter) with a pierced cap (cap: $90 \mathrm{~mm}$ in diameter, hole: $30 \mathrm{~mm}$ in diameter). The hole was covered with two pieces of Tetron gauze $(50 \mathrm{~mm}$ in diameter; T-No. 90T; NBC, Tokyo, Japan). Each container was kept at $20^{\circ} \mathrm{C}, 16 \mathrm{~h}$ light : $8 \mathrm{~h}$ dark, and was moistened if necessary. Within 2 weeks, 2295 adult scuttle flies (Phoridae) emerged from the four fruiting bodies. We chose the following 31 undamaged specimens for morphological identification: Megaselia flava (Fallén, 1823), 10'; M. kanekoi Disney, 1989, $110^{7}$ and 13 ; and M. gotoi Disney, 1989, $3 \sigma^{\prime \prime}$ and 3 q . Many species of scuttle fly are parasitoids or specialist predators, while some species, such as those in the genus Megaselia, are a significant component of the dipteran fauna of fungus sporophores (Hackman \& Meinander 1979; Disney 1994). Megaselia flava (referred to as Ophiochaeta matsutakei by Sasaki (1935) and Aphiochaeta matsutakei by Kiyoku (1958)) is a pest on the mushroom Tricholoma matsutake (referred to as Armillaria matsudake by Sasaki (1935) as cited by Disney (1994), and as the Japanese Pine mushroom by Kiyoku (1958), cited as T.edodes by Disney (1994)). In addition, $M$. flava has previously been reared from a wide range of fungal taxa, including Gymnopilus bybridus, Leccinum scabrum, Pluteus cervinus, Russula aeruginea, $R$. heterophylla, Peziza micropus, P. vesiculosa, P. varia and $P$. repanda (Disney 1994). The only previous record of this species reared from a species of Amanitaceae was from A. muscaria (Yakovlev 1994). Megaselia gotoi has been reared from A. farinosa and A. spissacea, and M. kanekoi has been reared from A. spissacea (Disney 1989). Amanita farinosa is phylogenetically related to A. pantherina and allies, including A. ibotengutake (Oda et al. 1999, 2002), and is suspected to be poisonous to humans (Seeger \& Stijve 1980), but ibotenic acid and muscimol were not detected (Chilton \& Ott 1976). Amanita spissacea is also suspected to be poisonous, but the toxic element of this fungus has not been elucidated.
The toxins ibotenic acid and muscimol were only found in A. muscaria, A. pantherina and their allies, including A. ibotengutake (Seeger \& Stijve 1980; Oda et al. 2002). Amanita spissacea is distantly related to those species (Oda et al. 1999), and it is unlikely that this fungus contains those toxins. Disney (1989) summarized four Megaselia species that were fungivores found with Amanita species containing ibotenic acid and muscimol (M. lata and M. rubella from A. muscaria, and M. lata, M. lutea and M. rubella from A. pantherina). Amanita ibotengutake, which contains ibotenic acid and muscimol, thus represents a previously undescribed host of M. flava, M. kanekoi and M. gotoi.

\section{ACKNOWLEDGMENTS}

This work was supported in part by a Grant-in Aid (15380104) to C. Tanaka for Scientific Research (B) from the Japan Society for the Promotion of Science, and the Center of Excellence (COE) for Microbial Process Development Pioneering Future Production Systems and Innovative Food and Environmental Studies Pioneered by Entomomimetic Sciences (COE programs of the Ministry of Education, Culture, Sports, Science, and Technology of Japan).

\section{REFERENCES}

Bresinsky A, Besl H (1990) A Colour Atlas of Poisonous Fungi. Wolfe Publishing, London.

Chilton WS, Ott J (1976) Toxic metabolites of Amanita pantherina, A. cothurnata, A. muscaria and other Amanita species. Lloydia 39, 150-157.

Disney RHL (1989) Six new species of Megaselia (Diptera, Phoridae) reared from fungi in Japan. Acta Entomologica Bohemoslovaca 86, 368-380.

Disney RHL (1994) Scuttle Flies: The Phoridae. Chapman and Hall, London.

Hackman W, Meinander M (1979) Diptera feeding as larvae on macrofungi in Finland. Annales Zoologici Fennici 16, 50-83.

Hanski I (1989) Fungivory: Fungi, insects and ecology. In: Wilding N, Collins NM, Harmond PM, Webber JF (eds) Insect-Fungus Interactions, pp 25-68. Academic Press, San Diego.

Jenkins DT (1977) A taxonomic and nomenclatural study of the genus Amanita section Amanita for North America. Bibliotheca Mycologica 57, 1-126.

Kiyoku M (1958) Studies on the insect fauna of the Japanese pine mushroom and the damage due to the insect pests. Scientific Reports of the Faculty of Agriculture of Okayama University 11, 49-59. (In Japanese with English summary.) 
Kukor JJ, Martin MM (1987) Nutritional ecology of fungusfeeding arthropods. In: Slansky F Jr, Rodriguez JG (eds) Nutritional Ecology of Insects, Mites, Spiders, and Related Invertebrates, pp 791-814. John Wiley and Sons, New York.

Martin MM (1979) Biochemical implications of insect mycophagy. Biological Reviews 54, 1-21.

Oda T, Tanaka C, Tsuda M (1999) Molecular phylogenies of Japanese Amanita species based on nucleotide sequences of the internal transcribed spacer region of nuclear ribosomal DNA. Mycoscience 40, 57-64.

Oda T, Yamazaki T, Tanaka C, Terashita T, Taniguchi N, Tsuda M (2002) Amanita ibotengutake sp. nov., a poisonous fungus from Japan. Mycological Progress 1, 355-365.

Sasaki C (1935) On a new Phoridae fly infesting our edible mushrooms. Proceedings of the Imperial Academy of Japan 11, 112-114.

Seeger R, Stijve T (1980) Occurrence of toxic Amanita species. In: Faulstich H, Kommerell B, Wielant T (eds) Amanita
Toxin and Poisoning, pp 3-17. Verlag Gerhard Witzstrock, Baden-Baden.

Takemoto T, Yokobe T, Nakajima T (1964) Studies on the constituents of indigenous fungi. II. Isolation of the flycidal constituent from Amanita strobiliformis. Yakugaku Zasshi 84, 1186-1188. (In Japanese with English summary).

Wheeler Q, Blackwell M (1984) Fungus-Insect Relationships. Perspectives in Ecology and Evolution. Columbia University Press, New York.

White TJ, Bruns T, Lee S et al. (1990) Amplification and direct sequencing of fungal ribosomal RNA genes for phylogenetics. In: Innis MA, Gelfand DH, Sninsky JJ, White TJ (eds) PCR Protocols: A Guide to Methods and Applications, pp 315-322. Academic Press, San Diego.

Yakovlev EB (1994) [Palearctic Diptera Associated with Fungi and Myxomycetes.] Karelian Research Center, Russian Academy of Sciences Forest Research Institute, Petrozavodsk. (In Russian.) 